\title{
Study of genetic resources for powdery mildew resistance by biochemical and physiological parameters on peaches and nectarines in Romania
}

\author{
Toma, S. ${ }^{1 *}$, Ivascu, A. ${ }^{1}$, Oprea, M. $^{2}$, Delian, E. ${ }^{3}$, Toma $^{3}$ F. \\ Zdremtan, M, ${ }^{4}$, Halmagean, L. ${ }^{4}$ and Cantar, L. ${ }^{4}$ \\ 'Research Station for Fruit Tree Growing Baneasa Bucharest, Bdv. Ion Ionescu de la Brad, No.4, sect.1, \\ code 71592 Bucharest, Romania \\ ${ }_{2}^{2}$ Plant Protection Institute Bucharest, Bdv. Ion Ionescu de la Brad, No.8, sect.1, code 71592, Bucharest, Romania \\ ${ }^{3}$ University of Agronomical Sciences Bucharest, Bdv. Marasti 59, code 77529, Bucharest, Romania \\ ${ }^{4}$ Aurel Vlaicu" University, Arad, Faculty of Food Industry, Tourism and The Environment Protection, str. Elena Drägoi no. \\ 3,2900 Arad, Romania
}

*Author for correspondence: tomastefania@hotmail.com

Summary: During 1997-2002, studies on the physiological and biochemical changes due to powdery mildew attack in peach and nectarine cultivars and hybrids belonging to different classes of resistance had been performed at the Research Station for Fruit Tree Growing (RSFTG) Baneasa Bucharest, located in the southern part of Romania. The study was based on disease assessments in the field and on other diagnosis criteria.

The southern part of Romania has favourable ecological conditions for growing peach and nectarine but trees have been attacked by various pathogens such as Sphaerotheca pannosa (Wallr.: Fr.) Lév. var. persicae Woronichin fungus for a long time. The presence of the pathogen causes important changes in the quantity and quality of fruits and affects the metabolism of trees.

This study was focused on several physiological and biochemical parameters such as photosynthesis and respiration intensity along with catalase activity; and changes in some biochemical compounds such as free, total and linked water content, dry matter, nitrogen and protein content, tannin levels. The aim was to find possible correlation among the above parameters and the biotic stress induced by the powdery mildew fungus calculated as attack degree (AD\%).

Results showed that photosynthesis diminished significantly in the case of the attacked phenotypes, the respiration was more intense in the infected cultivars and catalase proved to be less intense in the affected plants. The total water content significantly increased in contrast to the dry matter and tannin contents, which greatly reduced in the case of resistant cultivars such as 'Victoria', 'Nectared 7', 'HB 11-40'. The total nitrogen and protein levels showed less influence on resistance to powdery mildew on all cultivars. All genetic material found resistant to powdery mildew is currently used in peach and nectarine breeding programs in Romania.

Further studies focused on isolation and characterization of resistance genes for powdery mildew resistance will be done in the future based on data collected during several years.

Key words: Persica vulgaris, powdery mildew, biochemical compounds, physiological, resistance, cultivars

\section{Introduction}

A better understanding of the physiology and biochemistry of the diseased plant strongly contributes to the approach to disease resistance. Describing the resistance mechanisms against economically important and frequent pathogens such as Sphaerotheca pannosa (Wallr.: Fr.) Lév. var. persicae Woronichin were our goals.

Several studies have already proved that cultivar susceptibility has a key role in the effect of plant pathogens on fruit trees, such as in the case of apple scab and powdery mildew on apple (Aldwinckle \& Jones, 1990, Holb, 2000, Holb et al., 2001) or powdery mildew on peach and nectarines (Roselli \& Bellini, 1976; Simeone, 1987; Benedek et al. 1990, 1993; Ivascu \& Balan, 1994; Ivascu et al., 1996). It is difficult to fight against pathogens and pests in the case of fruit trees unless spending considerable sums on chemical treatments. Thus, one of the best ways remains to use resistant cultivars or in the future transgenic material expressing a durable resistance against diseases. However, there are several economical, knowledge-related and public acceptance issues on the latter topic.

As a result of the pathogen attack, the whole metabolism of the plant gets disturbed (Corazza \& Simeone, 1991; Ognjanov, 1996). In order to elucidate the resistance mechanisms against powdery mildew on peach and nectarine cultivars and hybrids, it seems compulsory to know the physiological and biochemical parameters' values in healthy tissues compared with the attacked ones.

lliev (1974) established that the pathogen attack on peach and nectarine was causing a desequilibrum in the hydric balance of the plant changing the water fixation capacity by 
the hydrophilic colloids. As far as we know, only few data are available on the biochemical parameters of peach and nectarine related to powdery mildew, despite the already existing genetic marker maps linked with powdery mildew resistance made by the French groups and others (Kervella et al., 1998). It has already been proved that the resistance to powdery mildew is controlled by poligenes and these should be clearly identified in order to be transferred later to the biological material to breed resistant plants. Also Ognjanov (1996) studied the polymorphism of peach germplasm using 16 specific isoenzymes. He established a correlation between the phenotype and specific isoenzymes insisting that morphological, anatomical and biochemical characteristics and resistance to powdery mildew were closely linked.

Aiming to check the effect of Sphaerotheca pannosa var. persicae fungus on plant metabolism, researchers tried to correlate the expressed field resistance with the internal modifications in the plant, such as physiological and biochemical changes (Toma \& Ivascu, 1997, Toma et al., 1998, 2003).

Tannins are known to have antibacterial and antifungal effects involved in plant resistance against diseases and based on this hypothesis we checked it in our experiments.

Studies done at RSFTG Baneasa on 56 peach and nectarine cultivars and hybrids showed that due to the attack of Sphaerotheca pannosa var. persicae fungus various physiological and biochemical parameters were affected. Respiration, photosynthesis, catalase activity, water content, dry matter, proteins and tannins were modified in the infected tissues compared with healthy ones. Out of the plant material studied, only one was selected from each resistance class for this presentation.

\section{Material and method}

According to our previous results, nectarine and peach cultivars and hybrids showed different behaviour to the pathogen under natural infections in the field. Out of 56 cultivars and hybrids, we presented here the following ones: 'Jerseyland', 'Victoria', 'Crimsongold', 'Nectared 7', 'HB 9 -9', 'HB 12 - 44', 'HB 11 - 40'.

Respiration intensity was determined by measuring the quantity of $\mathrm{CO}_{2}$ produced by the foliar mass in a given period of time with the help of $\mathrm{CO}_{2}$ type RIKEN analyser. Photosynthesis intensity was evaluated by gas chromatography.

Catalase activity was determined by measuring the gaseous exchange equilibrium in the moment when the enzyme activity was maximum. The reaction mixture consisted of phosphate buffer $\mathrm{pH} 7.0$ and $\mathrm{H}_{2} \mathrm{O}_{2}$. After the reaction the enzyme activity was estimated as $\mathrm{cm}^{3}$ of gas exchanged $\left(\mathrm{O}_{2}\right) /$ quantity of experimental working time.

Determinations of the water and dry matter contents were done by the measurement of weight losses due to sample heating at $105^{\circ} \mathrm{C}$. Plant water content shown as percentage of the fresh weight was estimated by the formula:

$$
\text { water } \%=\frac{\text { quantity of water losses }(\mathrm{g})}{\text { fresh weight }(\mathrm{g})} \cdot 100 .
$$

The dry matter content $(\%)$ shown as percentage of weight was calculated as:

$$
\text { dry matter } \%=100-\text { water } \% \text {. }
$$

The total nitrogen and protein contents were determined by the Kjeldahl-Grunning method. In order to obtain the protein content, the total nitrogen content value was multiplied by a 6.25 factor. The total protein content was calculated by the following equation:

$$
\text { protein } \%=N-n \frac{0.0014 \cdot 100}{G} \cdot 6.25 \text {, }
$$

in which: $N=\mathrm{ml}$ sulfuric acid $0.1 \mathrm{~N} ; \mathrm{n}=\mathrm{ml}$ sodium hydroxide $0.1 \mathrm{~N} ; G=$ sample weight $(\mathrm{g}) ; 0.0014=$ nitrogen quantity corresponding to $1 \mathrm{ml} 0.1 \mathrm{~N} \mathrm{H}_{2} \mathrm{SO}_{4} ; 6.25$ = factor for estimation of the results in total protein.

Tannin content based on the chemical reaction between potassium permanganate (in acidic medium) and tannins in the presence of indigo-carmine as colour indicator was calculated by the following equation:

$$
\text { Tannin } \%=1.04 \frac{b-c}{a} \text {, }
$$

in which: $a=\mathrm{ml}$ potassium permanganate corresponding to $10 \mathrm{ml} 0.1 \mathrm{~N}$ oxalic acid; $b=\mathrm{ml}$ potassium permanganate used for the titration of $20 \mathrm{ml}$ bleached solution; $c=\mathrm{ml}$ potassium permanganate used for the titration of $100 \mathrm{ml}$ filtrate.

\section{Results}

In healthy plants, the intensity of respiration $(\mathrm{mg} \mathrm{CO}$ $\mathrm{kg}^{-1} \mathrm{~h}^{-1}$ ) was greatly influenced by the presence of the pathogen and ranged between 438.6 and 529.4 for cv. 'Victoria' and cv. 'Crimsongold', respectively. In contrast, values of 546.4 and $684.9 \mathrm{mg} \mathrm{CO}_{2} \mathrm{~kg}^{-1} \mathrm{~h}^{-1}$ for cv. 'Victoria' and cv. 'Crimsongold' were recorded, respectively, in the infected tissues (Figure l).

Intensive respiration was recorded in the powdery mildew infected material. It is a direct consequence of the plant's reaction to the pathogen, as the pathogen's respiration is also being added to the respiration of the host.

A visible decrease in photosynthesis was recorded in the infected cultivars. $4.85 \mathrm{mg} \mathrm{CO}\left(\mathrm{dm}^{2}\right)^{-1} \mathrm{~h}^{-1}$ was registered on the strongly infected cultivars, which represented a 3.37 times reduction compared with the healthy ones, where $16.34 \mathrm{mg} \mathrm{CO} \mathrm{CO}_{2}\left(\mathrm{dm}^{2}\right)^{-1} \mathrm{~h}^{-1}$ photosynthesis value was calculated (Figure 2). 
The enzymatic activity inside the plant tissues attacked by Sphaerotheca pannosa var. persicae showed that catalase had a role in disease resistance.

Thus, the most intensive catalase activity $\left(10.00 \mathrm{cmc} \mathrm{O}_{2}\right.$ $\mathrm{min}^{-1}$ ) was registered at healthy plants of $\mathrm{cv}$. 'Victoria'. However, in the case of powdery mildew affected cultivars such as cv. 'Crimsongold', the catalase activity was only $1.40 \mathrm{cmc} \mathrm{O}_{2} \mathrm{~min}^{-1}$. (Figure 3).

Data based on our study regarding peach and nectarine water content proved that diseased tissues had a higher water content (total, free and linked) compared with the healthy ones (Figure 4).

The differences of total water content between infected plants and healthy ones oscillated between $5.06 \%$ and $0.42 \%$ on peach hybrid 'HB 9-9' and cv. 'Nectared 7', respectively. Maximum values of total water content were recorded at plants very sensitive to powdery mildew attack (data not presented).

Data has proved that the statistical correlation between degree of powdery mildew attack and total water content was linear, positive and significant $\left(\mathrm{R}^{2}\right.$ was above 0.9$)$ (Figure 5).

The healthy plants had a higher dry matter content compared with the powdery mildew infected ones in all plant material studied. The difference was $4.29 \%$ in the case of the peach hybrid , 'HB 9-9' and $0.69 \%$ in nectarine cv. 'Nectared 7' (Figure 6).

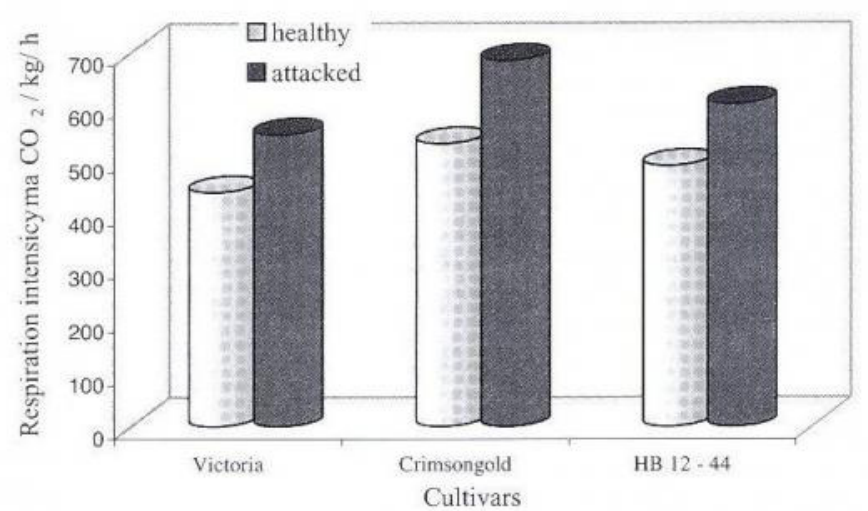

Figure 1 Respiration intensity $\left(\mathrm{CO}_{2} \mathrm{~kg}^{-1} \mathrm{~h}^{-1}\right)$ in three healthy and powdery mildew attacked peach and nectarine cultivars

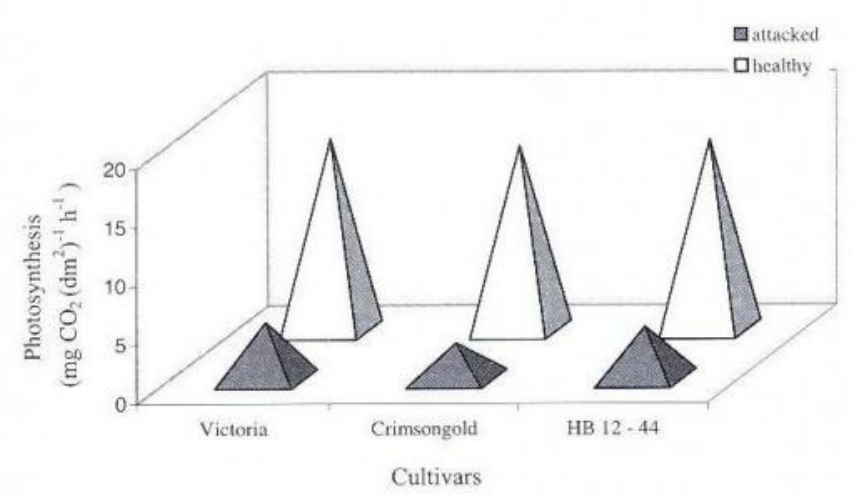

Figure 2 Photosynthesis intensity $\left(\mathrm{mg} \mathrm{CO}_{2}\left(\mathrm{dm}^{2}\right)^{-1} \mathrm{~h}^{-1}\right)$ in three healthy and powdery mildew attacked peach and nectarine cultivars
Our study showed that the correlation between the dry matter content and powdery mildew attack was linear, negative and significant (Figure 7).

This study demonstrated that there were practically no significant differences between powdery mildew diseased plants and the helathy plant material regarding total nitrogen and protein contents. But it seemed that generally the healthy plants had a little bit higher total nitrate content compared with powdery mildew infected ones (Figure 8).

Concerning the dynamics of the total nitrogen and protein contents, we observed an increase at the beginning of the

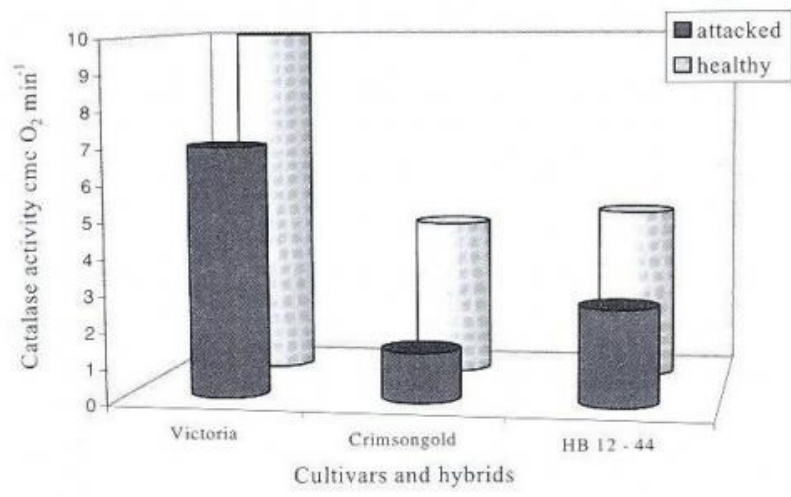

Figure 3 Catalase activity $\left(\mathrm{cmc} \mathrm{O}_{2} \mathrm{~min}^{-1}\right.$ ) in three healthy and powdery mildew attacked peach and nectarine cultivars

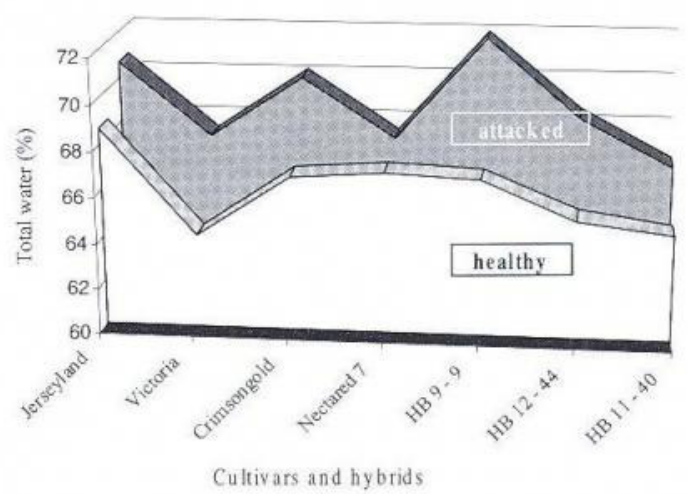

Figure 4 Total water content $(\%)$ in seven powdery mildew attacked and healthy peach and nectarine cultivars

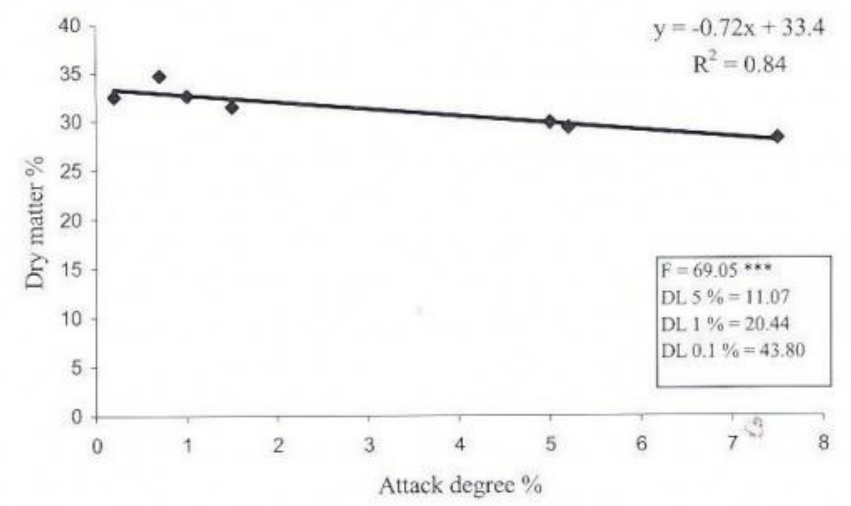

Figure 5 Relationship between the powdery mildew attack degree (AD\%) and the total water content $(\%)$ 


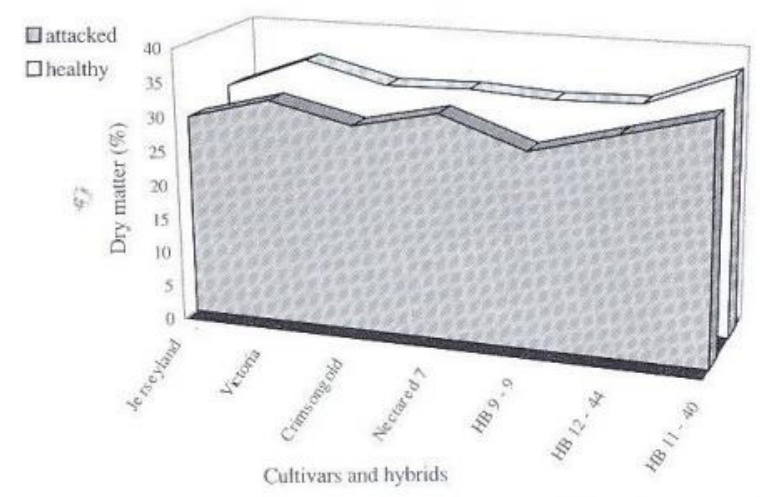

Figure 6 Dry matter content $(\%)$ in seven powdery mildew attacked and healthy peach and nectarine cultivars

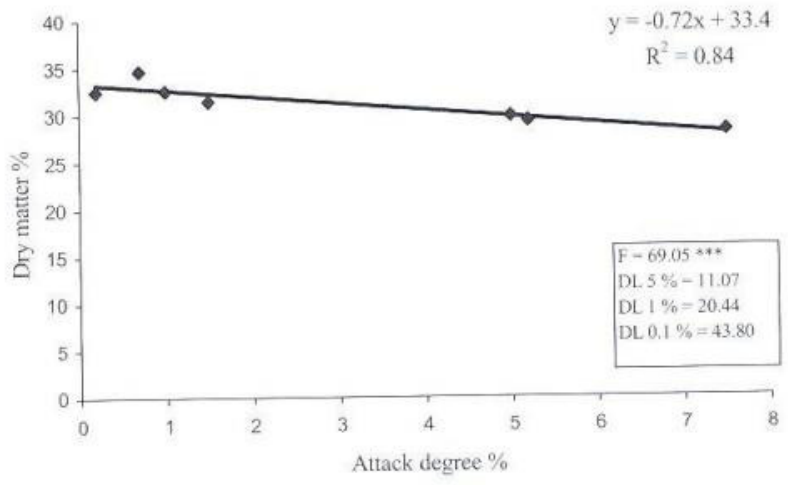

Figure 7 Relationship between the powdery mildew attack degree (AD\%) and the dry matter content (\%)

fruit growing period. Maximum values were in July, after this the total nitrogen and protein contents decreased.

Our research at RSFTG Baneasa Bucharest Romania during 1997-2002 demonstrated that the healthy plants have a higher tannin content than those attacked by the fungus Sphaerotheca pannosa var. persicae.

It was found that cultivars showed differences in the amount of tannin. Thus, tannin level was always higher in the powdery mildew resistant cultivars ('Victoria') compared to the susceptible ones ('Crimsongold'). In all plant tissues analyzed, tannin content was variable, $0.763 \%$ in cv. 'Victoria' and $0.445 \%$ in cv. 'Crimsongold' (Figure 9).

\section{Conclusions}

Based on our study on some physiological and biochemical parameters of peach and nectarine cultivars, powdery mildew infected or healthy, the following conclusions can be drawn:

- Sphaerotheca pannosa (Wallr.: Fr.) Lév. var. persicae Woronichin fungus attack on host tissues induces very important modifications in the physiological and biochemical parameters;

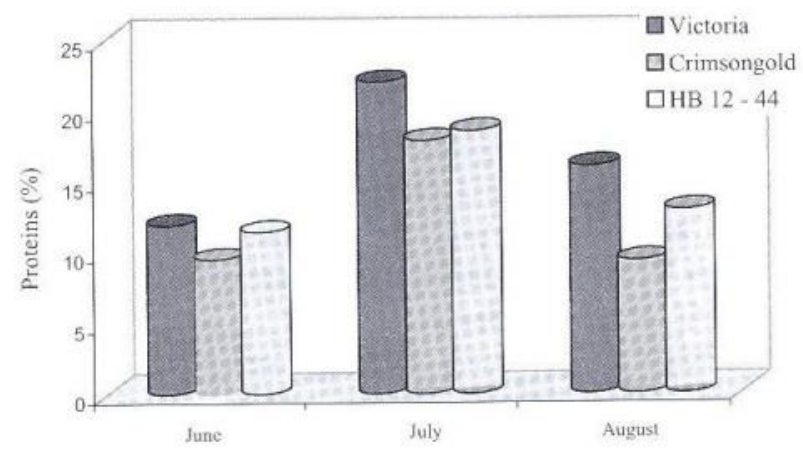

Figure 8 The protein content $(\%)$ in three healthy and powdery mildew attacked peach and nectarine cultivars

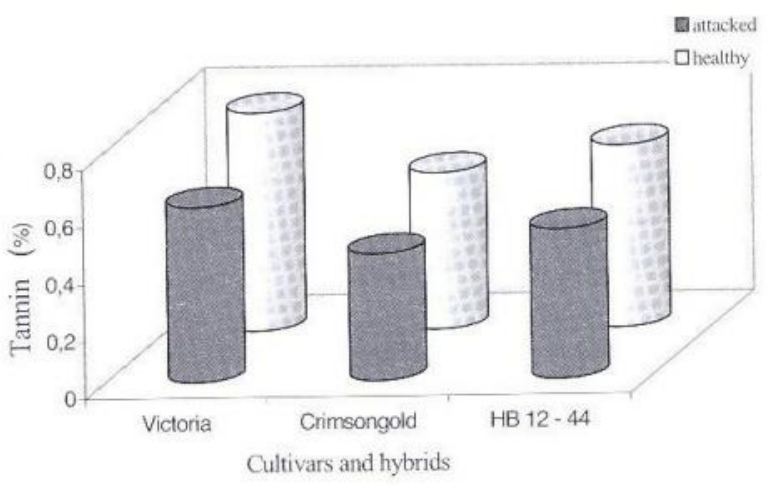

Figure 9 Tannin content $(\%)$ in three healthy and powdery mildew attacked peach and nectarine cultivars

- all powdery mildew susceptible cultivars and hybrids analyzed showed an increased total water content compared to the resistant ones;

- the statistical correlation between the degree of powdery mildew attack $(\mathrm{AD} \%)$ and the total water content was linear, positive and significant;

- on the contrary, the dry matter content was higher in the healthy tissues compared with the powdery mildew affected ones;

- total nitrogen and protein contents were probably not directly involved in the powdery mildew resistance since the values of these parameters were very similar at healthy and infected plant material, but more detailed studies are being conducted on it;

- the intensity of respiration was always higher in the powdery mildew affected plants;

- photosynthesis was reduced in the powdery mildew affected tissues because of the reduction of the assimilation by the leaves;

- catalase activity was lower in the susceptible cultivars compared with the resistant ones; 
- for a better understanding of the resistance mechanisms against pathogens including powdery mildew more molecular studies will be undertaken in the near future at RSFTG Baneasa Bucharest Romania.

\section{References}

Benedek P., Nyéki J. \& Vályi I. (1990): Csonthéjas gyümölesfajták érzékenysége a fontosabb kórokozókkal és kártevốkkel szemben - a fajtaspecifikus növényvédelmi technológia kidolgozása. Növényvédelem 26: 12-31.

Benedek P., Szabó Z., Soltész M., Nyéki J. \& Kovács J. (1993): Fruit varieties, plant disease susceptibility, pest control and cultivar improvement. Hungarian Agricultural Research. 2 (2): 4-10.

Corzza, L. \& Simeone, A. M. (1991): Particular aspects of brown rot and powdery mildew epiphytotics on apricot. Acta Horticulturae, 293: 515-520.

Holb I. J. (2000): Disease progress of apple scab caused by Venturia inaequalis in environmentally friendly growing systems. International Journal of Horticultural Science 6. (4): 56-62.

Holb I. J., Gonda I. \& Bitskey K. (2001): Pruning and incidences of diseases and pests in environmentally friendly apple growing systems: some aspects. International Journal of Horticultural Science 7. (1): 24-29.

Iliev, I. (1974): Studies on the ontogenetic sensitivity of peach and nectarines fruits to powdery mildew Sphaerotheca pannosa (Wallr.) Lev. var. persicae. Horticultural Abstracts 5491vol. 42: 651.

Ivascu, A. \& Balan, V. (1994): Behaviour of some peach and nectarine cultivars and hybrids at the attack of mildew under the climatic conditions of the southern area of Romania. The XXIV-th Int. Hort. Congres Kyoto, Japan, 21-27 Aug.

Ivascu, A., Balan, V. \& Toma, S. (1996): Peach and nectarine genitors with highly resistant to powdery mildew. Scientific Sessions ICPP vol. XIX, Pitesti

Jones, A. L. \& Aldwinckle, H. S. (1990): Compendium of Apple and Pear Diseases. APS Press. St. Paul, Minnesota.

Kervella, J, Pascal, T., Pfeiffer, F. \& Dirlenwanger, E. (1998): Breeding for multiresistance in peach trees, Acta Horticulturae 465: 177-181.

Ognjanov, I. (1996): Mildew resistance in peach. University of Novi Sad rewies. D. Obradovica, 8, Yugoslavia

Roselli, G. \& Bellini, E. (1976): Indagini sulla suscettibilita all oidio Sphaerotheca pannosa (Wallr.) Lev. var. persicae in una collezione di cultivar di pesco. Rivista dell'Ortoflorofruticultura italiana, 1: 60-66.

Simeone, A. M. (1987): Osservazioni su alcuni caratteri morfologici e sulla sensibilita del pesco (Prunus persica vulgaris Stokes.) alla Sphaerotheca pannosa (Wallr. Fr.) Lev. e alla Taphrina deformans Berk. Tull., Informattore fitopatologico, XXXVII, Roma 24: 14-20.

Toma, S., Ivascu, A. \& Oprea, M. (1998): Highlights of epidemiology of the fungus sphaerotheca pannosa (wallr.) lev. var. persicae woron in the southern zone of Romania. Acta Hort. 465: 709-714.

Toma, S. \& Ivascu, A., (1997): Behaviour of some peach and nectarine varieties and hybrids to mainly diseases: leaf curl and powdery mildew in Romania. Int. Hort. Sci. Conf., Lednice na Morave, 9 - 12 September.

Toma, S., Ivascu, A., Oprea, M. \& Delian E. (2003): Evaluation of powdery mildew resistance at some peach and nectarine cultivars and hybrids by physiological parameters, Acta Hort. 623: 291-298. 